\title{
Budesonide and formoterol effects on rhinovirus replication and epithelial cell cytokine responses
}

\author{
Yury A Bochkov ${ }^{1 *}$, William W Busse ${ }^{2}$, Rebecca A Brockman-Schneider ${ }^{1}$, Michael D Evans ${ }^{3}$, Nizar N Jarjour ${ }^{2}$, \\ Christopher McCrae ${ }^{4}$,Anna Miller-Larsson ${ }^{4}$ and James E Gern ${ }^{1,2}$
}

\begin{abstract}
Background: Combination therapy with budesonide and formoterol reduces exacerbations of asthma, which are closely associated with human rhinovirus (RV) infections in both children and adults. These data suggest that budesonide and formoterol inhibit virus-induced inflammatory responses of airway epithelial cells.

Methods: To test this hypothesis, bronchial epithelial (BE) cells were obtained from airway brushings of 8 subjects with moderate-to-severe allergic asthma and 9 with neither asthma nor respiratory allergies. Cultured BE cells were incubated for 24 hours with budesonide $(1.77 \mu \mathrm{M})$, formoterol $(0.1 \mu \mathrm{M})$, both, or neither, and then inoculated with

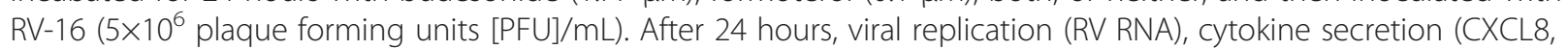
CXCL10, TNFa, IFN- $\beta$, IL-28) and mRNA expression (CXCL8, CXCL10, TNF, IFNB1, IL28A\&B) were analyzed.

Results: RV infection induced CXCL10 protein secretion and IFNB1 and IL28 mRNA expression. Drug treatments significantly inhibited secretion of CXCL10 in mock-infected, but not RV-infected, BE cells, and inhibited secretion of TNFa under both conditions. Neither budesonide nor formoterol, alone or in combination, significantly affected viral replication, nor did they inhibit RV-induced upregulation of IFNB1 and IL28 mRNA. Overall, RV replication was positively related to CXCL10 secretion and induction of IFNB1 and IL28 mRNA, but the positive relationship between RV RNA and CXCL10 secretion was stronger in normal subjects than in subjects with asthma.

Conclusions: Budesonide and formoterol can inhibit BE cell inflammatory responses in vitro without interfering with viral replication or production of interferons. These effects could potentially contribute to beneficial effects of budesonide/formoterol combination therapy in preventing RV-induced asthma exacerbations.
\end{abstract}

Keywords: Budesonide, Formoterol, Human rhinovirus, Bronchial epithelial cells, Asthma

\section{Background}

Infections with human rhinoviruses (RVs) are commonly associated with increased symptoms and acute exacerbations of asthma that require treatment in the emergency department or hospitalization. In fact, RV infections are more often detected during acute exacerbations than any other respiratory virus $[1,2]$. This close association has led to research efforts directed at identifying treatment to prevent RV-induced exacerbations of asthma.

Several medications have shown efficacy for prevention of asthma exacerbations in general. Combination therapy with an inhaled corticosteroid (ICS) together with long-

\footnotetext{
* Correspondence: yabochkov@wisc.edu

${ }^{1}$ Department of Pediatrics, University of Wisconsin-Madison, 600 Highland

Avenue, K4/945 CSC, Madison, WI 53792-9988, USA

Full list of author information is available at the end of the article
}

acting beta agonist (LABA) is particularly effective at preventing exacerbations [3,4]. Results of clinical studies also suggest that both ICS and combination medications prevent exacerbations during the common cold season, and exacerbations that are associated with symptoms of the common cold [5,6].

Defining mechanisms of these effects is important to improving the efficacy of medications that prevent exacerbations, and several mechanisms have been proposed. First, RVs initiate infections by first binding to cell surface receptors on airway epithelial cells. Notably, ICS can downregulate in vitro expression of intercellular adhesion molecule 1 (ICAM-1), which is the cellular receptor for 89 of the 100 canonical RV-A and RV-B types [7,8]; however, glucocorticoid treatment did not prevent the increased ICAM-1 expression after experimental RV-16 infection
C Biomed Central 
[9]. Second, RVs cause illnesses in part by inducing release of pro-inflammatory chemokines and cytokines from infected epithelial cells. These factors include chemoattractants for neutrophils (e.g. CXCL8), mononuclear cells and T cells (e.g. CXCL10), and cytokines such as TNF $\alpha$ that can potentiate inflammatory cell functions [10-13]. ICS can inhibit the RV-induced production of both proinflammatory mediators [14] and type I interferons (e.g. IFN- $\alpha$ ) that have antiviral effects [15]. Clinical studies have shown evidence of this effect in vivo in that either systemic or topical corticosteroids were associated with increased RV replication after experimental inoculation with virus; however, cold severity was not affected [16].

We hypothesized that the combination of budesonide and formoterol would inhibit virus-induced inflammatory responses of primary airway epithelial cells in vitro. To test this hypothesis, we conducted a series of experiments with bronchial epithelial (BE) cells that were obtained from subjects with or without allergic asthma. As a secondary objective, we compared viral replication and RV-induced responses in cells from subjects with and without allergic asthma.

\section{Methods}

\section{Study subjects}

Primary BE cells were obtained from bronchial brushings of normal subjects and those with moderate to severe allergic asthma (Table $1, n=17$ ). The subjects with allergic asthma were treated with inhaled or oral corticosteroids, and these medications were continued up until the time of bronchoscopy for reasons of safety. The study protocol was approved by the University of Wisconsin-Madison Human Subjects Committee. After obtaining informed consent, lung function tests and methacholine responsiveness were determined as described previously [17]. Skin testing was performed to detect IgE specific for aeroallergens of local importance in Madison, WI [17]. In the asthma group, all subjects had $\mathrm{PC}_{20}<8 \mathrm{mg} / \mathrm{mL}$ or $>12 \%$ reversibility in $\mathrm{FEV}_{1}$ after bronchodilator, and all had positive skin tests for aeroallergen-specific IgE. In the normal group, lung function tests were normal, and there was no evidence of either bronchial hyperresponsiveness or allergic sensitization.

\section{Bronchial epithelial cells}

BE cells from bronchial brushings were cultured as described previously $[11,18]$. Briefly, the cells were removed from the brush by scraping and vigorous agitation in Dulbecco's Modified Eagle Medium: Nutrient Mixture F-12 (DMEM/F12, Life Technologies, Grand Island, NY), and then placed in tissue culture in collagen coated plasticware at $37^{\circ} \mathrm{C}\left(5 \% \mathrm{CO}_{2}\right)$ in Bronchial Epithelial Growth Medium (BEGM, Lonza, Walkersville, MD) in

Table 1 Study Subjects

\begin{tabular}{|c|c|c|c|c|c|c|c|}
\hline Subject & Group & Gender & Age & $\mathrm{PC}_{20}(\mathrm{mg} / \mathrm{mL})$ & FEV1 \% predicted & Reversibility* (\%) & Allergen Skin Test \\
\hline 1 & $\mathrm{~N}$ & $M$ & 24 & 20 & 86 & 7 & neg \\
\hline 2 & N & M & 21 & 20 & 99 & 5 & neg \\
\hline 3 & N & M & 22 & 50 & 101 & 7 & neg \\
\hline 4 & N & M & 21 & 50 & 90 & 5 & neg \\
\hline 5 & N & $\mathrm{F}$ & 20 & 50 & 86 & 6 & neg \\
\hline 6 & N & M & 40 & 50 & 101 & 1 & neg \\
\hline 7 & $N$ & M & 30 & 50 & 106 & 4 & neg \\
\hline 8 & N & $\mathrm{F}$ & 24 & 50 & 99 & 3 & neg \\
\hline 9 & N & $\mathrm{F}$ & 21 & 16 & 102 & 6 & neg \\
\hline Mean & & & & 36 & 97 & 5 & \\
\hline 10 & A & $\mathrm{F}$ & 20 & 4.2 & 101 & 6 & pos \\
\hline 11 & A & $\mathrm{F}$ & 20 & 0.4 & 98 & -2 & pos \\
\hline 12 & A & $M$ & 52 & nd & 48 & 22 & pos \\
\hline 13 & A & $\mathrm{F}$ & 36 & 0.3 & 64 & 51 & pos \\
\hline 14 & A & $M$ & 46 & nd & 62 & 14 & pos \\
\hline 15 & A & $\mathrm{F}$ & 24 & 0.9 & 94 & 4 & pos \\
\hline 16 & A & $M$ & 27 & 0.3 & 55 & 27 & pos \\
\hline 17 & A & $M$ & 21 & 0.8 & 80 & 15 & pos \\
\hline Mean & & & & 0.7 & 75 & 17 & \\
\hline
\end{tabular}

Definition of abbreviations: N, normal; A, asthma; nd, not done; $\mathrm{PC}_{20}$, provocative concentration of methacholine causing a $20 \%$ fall in FEV1; FEV1, forced expiratory volume in one second.

*Change in FEV1 after inhaling 2 puffs of albuterol. 
$25 \mathrm{~cm}^{2}$ flasks (passage 0), then expanded in $75 \mathrm{~cm}^{2}$ flasks (passage 1), and finally seeded in 12-well plates (passage 2). Purified and concentrated RV-16 [19] was diluted in BEGM with a reduced concentration $\left(10^{-8} \mathrm{M}\right)$ of hydrocortisone (low Hc BEGM) just before infection. Stock solutions of budesonide (anhydrous) and formoterol fumarate (dihydrate) were prepared in DMSO at a concentration of $10 \mathrm{mM}$, subsequent dilutions were made in low Hc BEGM (final concentration of DMSO applied to cells was $\leq 0.01 \%$ ). When the cell monolayers (duplicate wells) from each study subject (passage 2) were approximately $70-80 \%$ confluent, they were pre-treated for $24 \mathrm{~h}$ with budesonide $(1.77 \mu \mathrm{M})$, formoterol $(0.1 \mu \mathrm{M})$, both (at recommended therapeutic ratio of $17.7: 1$ ), or neither (0.01\% DMSO drug vehicle), and then either infected with $0.25 \mathrm{~mL}$ of $\mathrm{RV}-16\left(5 \times 10^{6}\right.$ plaque forming units $[\mathrm{PFU}] / \mathrm{mL})$, or mock-infected with medium alone for $2 \mathrm{~h}$ at $34^{\circ} \mathrm{C}$. Cell monolayers were then washed three times with PBS before adding fresh low Hc BEGM. After $24 \mathrm{~h}$ incubation at $34^{\circ} \mathrm{C}\left(5 \% \mathrm{CO}_{2}\right)$, cell supernatants were collected, the monolayers were washed with phosphate buffered saline and lysed by adding TRIzol Reagent (Invitrogen, Carlsbad, CA). Supernatant and cell lysate samples were stored in microcentrifuge tubes at $-80^{\circ} \mathrm{C}$ until RNA extraction and cytokine analysis.

\section{Virology}

The major receptor group RV-16 was chosen for this study because major group viruses replicate well in cultured BE cells without causing marked cytopathic effects [11], and thus is a good model of in vivo infections [20]. Stocks of virus were grown in HeLa cells and purified by sucrose gradient centrifugation as described previously [21].

\section{Measurement of viral and cellular RNAs}

Total RNA was isolated from the frozen TRIzol lysates according to manufacturer's protocol, treated with RQ1 DNase (Promega, WI, USA) and then purified by the RNeasy Mini Kit (Qiagen, Hilden, Germany). First-strand cDNA synthesis was performed using the TaqMan Reverse Transcription reagents and random hexamers (Life Technologies, Grand Island, NY). PCR was performed as previously described [18] using the primers shown in Table 2. Power SYBR Green PCR master mix (Life Technologies) was used to perform the reactions. Fold differences were determined by the $2^{-\Delta \Delta C t}$ method. The cycle threshold $(\mathrm{Ct})$ of each transcript was normalized to the $\mathrm{Ct}$ of the house-keeping gene peptidylprolyl isomerase A (PPIA) [22]. IL28 primers detect both IL28A and IL28B mRNAs due to their high sequence identity. We used RV primers and probe as described previously [20]. A standard curve was derived from purified RV-16 prep
Table 2 Real-time PCR primers used for mRNA quantification

\begin{tabular}{cccc}
\hline Target gene & Sequence( 5'-3') $^{\prime}$ & $\begin{array}{c}\text { Primer } \\
\text { length }\end{array}$ & $\begin{array}{c}\text { Amplicon } \\
\text { size (bp) }\end{array}$ \\
\hline PPIA-f $^{\dagger}$ & TCATCTGCACTGCCAAGACTG & 21 & \\
PPIA-r $^{\dagger}$ & CATGCCTCTTCACTTGGC & 21 & 71 \\
IFNB1-f & AGGACGCCGCATTGACC & 17 & \\
IFNB1-r & ATTCCAGCCAGTGCTAGATGA & 21 & 83 \\
IL28-f & GCTGACCGTGACTGGAGCA & 19 & \\
IL28-r & GACAGGGACTTGAACTGGGCTA & 22 & 93 \\
TNF-f & TCGGCCCGACTATCTCGAC & 19 & \\
TNF-r & GCGTTGGGAAGGTTGGAT & 19 & 94 \\
CXCL10-f & AAGCTCTACTGAGGTGCTATGTT & 23 & \\
CXCL10-r & TGGGAAAGGTGAGGGAAATA & 20 & 72 \\
CXCL8-f & CAGTTTGCCAAGGAGTGCTAA & 22 & \\
CXCL8-r & GGTGGAAAGGTTTGGAGTATGTC & 23 & 69 \\
\hline
\end{tabular}

Definition of abbreviations: $\mathrm{f}$, forward primer; $\mathrm{r}$, reverse primer; $\mathrm{bp}$, base pairs. ${ }^{\dagger}$ The PPIA primer sequences were published by RTPrimerDB, ID \#3460 (http://medgen.ugent.be/rtprimerdb/).

of known infectivity, and results are reported in PFU equivalents (PFUe).

\section{Measurement of cytokine proteins}

CXCL8, CXCL10, TNF $\alpha$ and IL-28 concentrations were assessed using human Cytokine / Chemokine Milliplex map kits (Millipore, Temecula, CA) according to the manufacturer's instructions. Luminex 100 instrument (Luminex Corporation, Austin, TX) was used to run plates and generate quantitative data. Sensitivity of the assays (minimum detectable concentration) was $0.3 \mathrm{pg} /$ $\mathrm{mL}$ (CXCL8), $2.2 \mathrm{pg} / \mathrm{mL}$ (CXCL10), $7.9 \mathrm{pg} / \mathrm{mL}$ (IL-28) and $0.1 \mathrm{pg} / \mathrm{mL}$ (TNF $\alpha)$. IFN- $\beta$ secretion was determined by ELISA (R\&D Systems, Minneapolis, MN) according to the manufacturer's instructions. The lower limit of IFN- $\beta$ detection was $50 \mathrm{pg} / \mathrm{mL}$.

\section{Data analysis}

Mixed-effects ANOVA models were used for all analyses to account for repeated measures in subjects. All responses were log-transformed for analysis except CXCL8 protein. Means and confidence intervals (CIs) of log-transformed responses were back-transformed and reported on the original scale of measurement. In the absence of significant interaction effects, the main effects for asthma status, RV versus mock treatment, and drug, are reported. Associations between viral RNA and cytokine mRNA and protein levels were tested in linear models of CXCL10 with RV, asthma, and RV $\times$ asthma interaction as covariates. Pearson correlation coefficients were calculated for relationships between RV and cytokine mRNA and protein. $\mathrm{P}$ values $<0.05$ were considered statistically significant. 


\section{Results}

\section{Viral replication}

Measurements were performed in cell lysates (RV RNA, cytokine mRNA) and supernatants (cytokine protein) collected $24 \mathrm{~h}$ post inoculation. When all subjects $(n=17)$ were considered together, the geometric mean of RV-16 RNA was $5.3 \times 10^{6}\left(3.2 \times 10^{6}, 8.8 \times 10^{6}, 95 \% \mathrm{CI}\right) \mathrm{PFUe}$ per sample in the absence of drug treatment (Figure 1A). Treatment with budesonide and/or formoterol had no effect on RV replication (Figure 1A, $p=0.43$ ). We next examined effects of allergic asthma on viral replication and induction of cytokines in ANOVA models including subject, asthma status, and drug treatment group. Overall, viral replication tended to be greater in cells from normal subjects compared to cells from subjects with asthma $\left(7.6 \times 10^{6}\left[4.1 \times 10^{6}, 14.2 \times 10^{6}\right]\right.$ vs. $3.3 \times 10^{6}\left[1.7 \times 10^{6}\right.$, $\left.3.3 \times 10^{6}\right]$ PFUe, $p=0.06$; Figure 1B).

\section{Drug effects on cytokine induction}

RV-16 infection significantly induced secretion of CXCL10 (44 [7.0, 249] vs. 7.2 [5.3, 9.8] pg/mL geometric means [95\% CI], $p<0.001$ ), but not TNF $\alpha$ or CXCL8 (Figure 2). We also tested for IL-28 and IFN- $\beta$ secretion, but these cytokines were not detectable in most samples, and we therefore analyzed IL28 and IFNB1 mRNA expression by qPCR. Compared to mock-infected cells and in the absence of drug treatment, RV induced small amounts of IFNB1 mRNA $(2.2[1.4,2.2]$ fold increase $)$ and larger amounts of IL28 mRNA (32.2 [14.1, 73.6] fold increase) (Figure 3), but did not induce TNF or CXCL8 mRNA (data not shown).

In mock-infected cells, treatment with budesonide, formoterol, and the combination of both drugs significantly inhibited secretion of CXCL10 and TNF $\alpha$ compared to cells without drug treatment (Table 3). None of the drug treatments had significant effects on CXCL8 secretion in mock-infected cells.
In RV-infected samples, treatment with both drugs alone and the combination inhibited secretion of TNF $\alpha$, but effects on CXCL10 were not significant (Table 3). Treatment with either budesonide or the combination of budesonide and formoterol also inhibited CXCL8 secretion after RV infection. There were no significant treatment effects of budesonide, formoterol, or the combination on RV-induced IFNB1 or IL28 mRNAs $(p=0.27$ and 0.14 respectively, Table 3).

\section{Asthma effects on cytokine induction}

Asthma appeared to modify RV-induced secretion of CXCL10 and TNF $\alpha$ (Table 4) in that RV infection stimulated increased secretion of these cytokines only in subjects without asthma (asthma $\times$ RV interaction $p$ values: CXCL10, 0.003; TNF $\alpha, 0.0003)$. Similarly, asthma was associated with lower fold increases in RV-induced IFNB1 mRNA $(p=0.01)$ and IL28 mRNA $(p=0.009)$. There were no effects of asthma on secretion of CXCL8 (data not shown).

Given the trend for less viral replication in the samples from subjects with asthma, we conducted a post hoc analysis to determine whether asthma status affected RV induction of cytokine protein and mRNA. Overall, there was a positive correlation between RV RNA levels and induction of both IFNB1 mRNA $(r=0.69, p<0.001)$ and IL28 mRNA $(r=0.71, p<0.001)$, and this relationship was not affected by asthma status (Figures $4 \mathrm{~A}$ and 4B; interaction terms $p=0.36$ for IFNB1 and $p=0.54$ for IL28). In contrast, there was a positive correlation between RV RNA level and CXCL10 secretion in cells from normal individuals $(r=0.36, p=0.01)$, but not in cells from subjects with asthma $(r=0.17, p=0.48$; interaction term $\mathrm{p}=0.07$; Figure $4 \mathrm{C}$ ). For example, a 10 -fold increase in RV RNA was associated with a 11 -fold increase (95\% CI 1.9, 70) in CXCL10 secretion in the normal group, compared to only a 1.5 fold increase $(95 \%$ CI $0.49,4.6)$ in the asthma group.
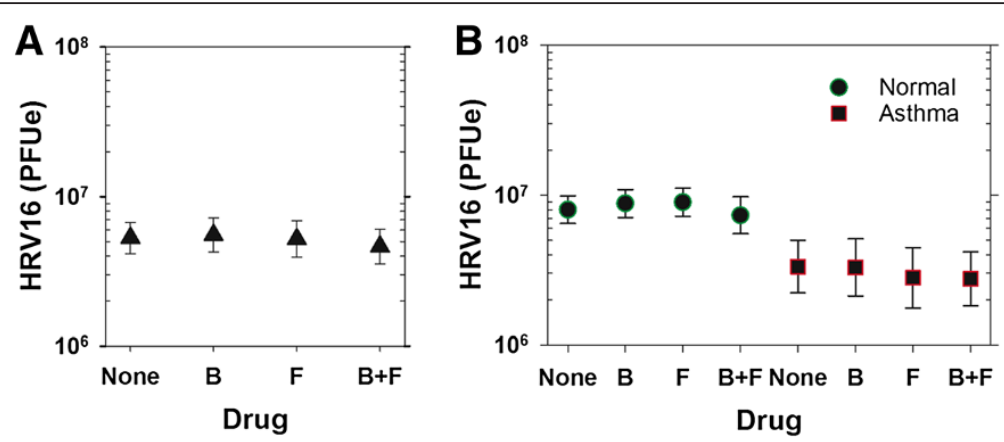

Figure 1 Viral replication in BE cells from normal and asthmatic subjects was not affected by budesonide or formoterol. Cells were inoculated with RV-16 after $24 \mathrm{~h}$ pre-treatment with budesonide (B), formoterol (F), both drugs (B+F), or media alone (none) and cell-associated viral RNA was measured $24 \mathrm{~h}$ post-inoculation. Neither $\mathrm{B}, \mathrm{F}$, nor the combination significantly affected RV replication in all samples $(\boldsymbol{A})$, nor in samples grouped according to asthma status $(\boldsymbol{B})$. Data are represented as geometric means with $95 \%$ confidence intervals. 


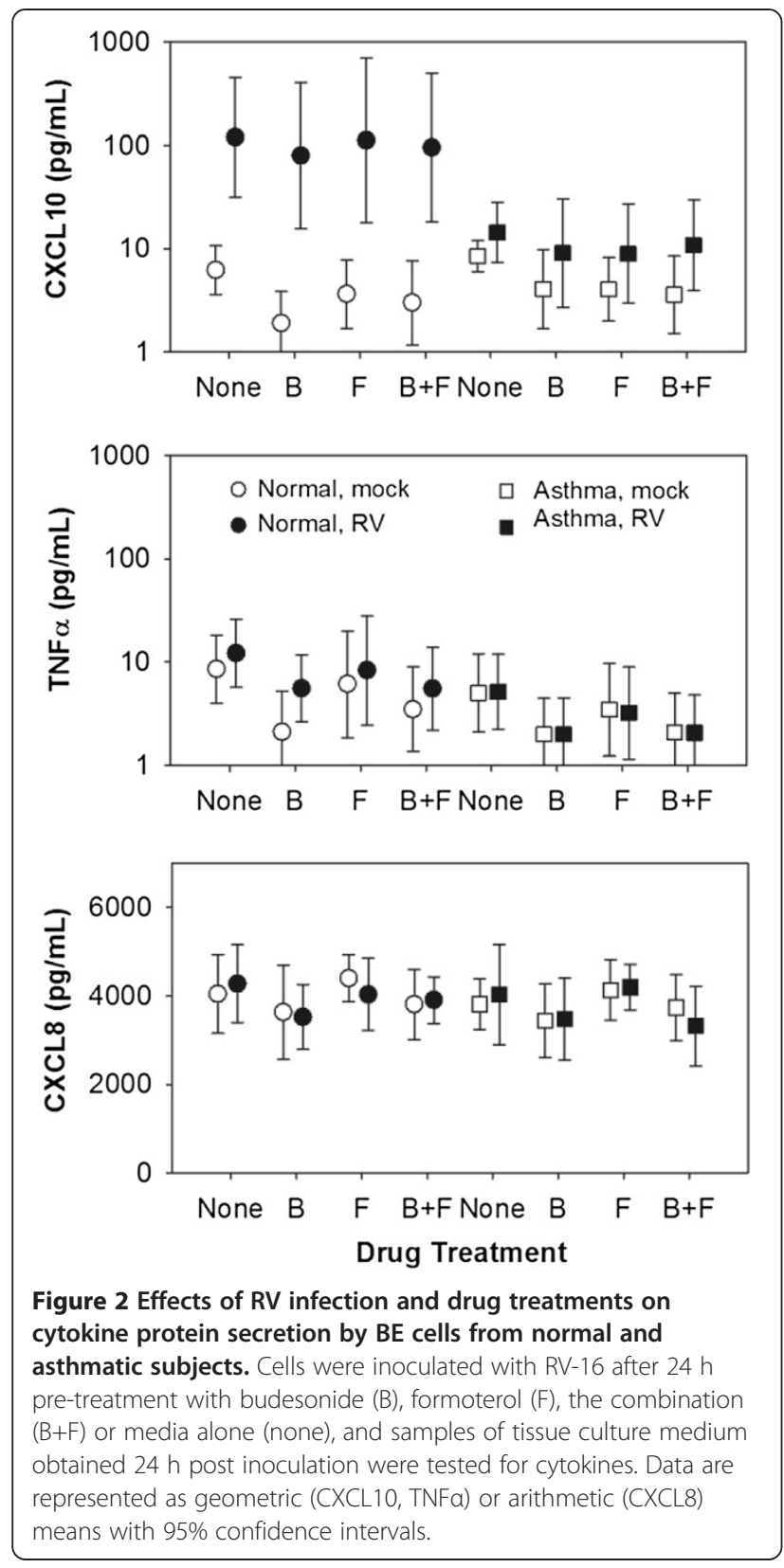

To determine whether this difference was related to measurement of protein vs. mRNA, we also compared RV RNA to induction of CXCL10 mRNA. RV RNA was positively correlated with CXCL10 mRNA in both groups (no asthma $r=0.61, p<0.0001$; asthma $r=0.57$, $p<0.0001$ ), but the slope was significantly greater in the no asthma group (interaction term $p=0.0008$; Figure 4D). In this case, a 10-fold increase in RV RNA was associated with a 56 -fold increase $(95 \%$ CI 14, 230) in CXCL10 mRNA in the normal group, compared to a 2.8 -fold increase $(95 \%$ CI 1.2, 6.8) in CXCL10 mRNA in the asthma group.

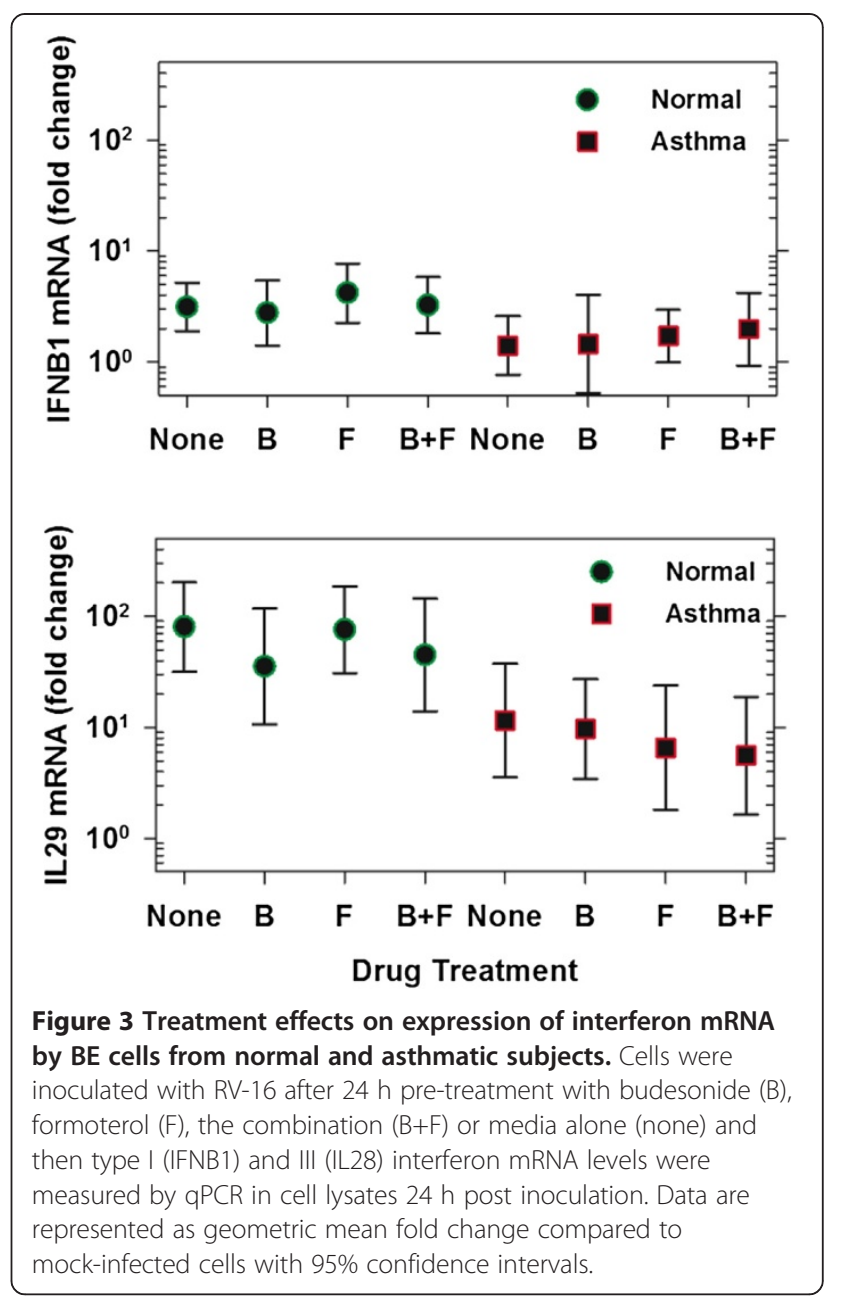

\section{Discussion}

In addition to serving as host cells for viral infections, airway epithelial cells are important initiators of the local antiviral immune response through the production of chemokines, pro-inflammatory cytokines, and interferons [23]. These studies were conducted to determine the effects of budesonide, formoterol and the combination of these two drugs on RV-induced cytokine responses of cultured primary BE cells. Because primary cells obtained by bronchoscopy are usually low in number and have limited growth potential, we have used high but still clinically relevant concentration of drugs that had shown strong inhibitory effects in vitro [24-26] instead of testing multiple drug concentrations. The results show that RV infection stimulated CXCL10 secretion and an antiviral response as indicated by induction of IFNB1 and IL28 mRNA. Secretion of CXCL10 was significantly inhibited by budesonide, formoterol and their combination in mock-infected cells, but none of the treatments significantly affected RV-16-induced CXCL10 secretion. Notably, budesonide, formoterol or their combination did not significantly affect antiviral responses as measured by IFNB1 and IL28 mRNA 
Table 3 Effects of drugs on cytokine secretion by BE cells from all subjects (mean ${ }^{\dagger}, 95 \% \mathrm{Cl}, n=17$ )

\begin{tabular}{lcccc}
\hline Mock-infected & \multicolumn{3}{c}{ Drugs } \\
\cline { 2 - 5 } & None & Budesonide & Formoterol & Both \\
\hline CXCL8 & $3940(3454,4426)$ & $3546(2935,4157)$ & $4279(3901,4657)$ & $3780(3292,4268)$ \\
CXCL10 & $7.2(5.3,9.8)$ & $2.7(1.6,4.6)^{* *}$ & $3.8(2.4,6.1)^{* *}$ & $3.3(1.8,5.8)^{* *}$ \\
TNFa & $6.7(3.9,11)$ & $0.5(0.2,1.4)^{* *}$ & $2.4(0.7,7.8)^{*}$ & $0.8(0.2,2.6)^{* *}$ \\
RV-infected & & & & $3634(3164,4104)^{*}$ \\
CXCL8 & $4163(3540,4786)$ & $3504(2993,4015)^{* *}$ & $4116(3675,4557)$ & $34(12,99)$ \\
CXCL10 & $44(7.0,249)$ & $29(9.8,84)$ & $34(11,112)$ & $1.3(0.4,4.4)^{* *}$ \\
TNFa & $8.1(4.7,14)$ & $1.5(0.5,4.6)^{* *}$ & $2.7(0.8,9.2)^{* *}$ & $2.6(1.7,4.0)$ \\
IFNBI mRNA & $2.2(1.4,3.2)$ & $2.0(1.2,3.8)$ & $2.8(1.8,4.3)$ & $17(6.7,42)$ \\
IL28 mRNA & $32(14,74)$ & $19(8.9,42)$ & $24(9.4,61)$ & $17.45)$
\end{tabular}

${ }^{\dagger} \mathrm{CXCL8}$ arithmetic mean, others represent geometric means; cytokine protein values represent $\mathrm{pg} / \mathrm{mL}$, and $\mathrm{mRNA}$ are presented as fold increase after RV infection. * $\mathrm{P} \leq 0.05$ drug vs. no drug.

** $\mathrm{P} \leq 0.005$ drug vs. no drug.

expression, nor did they significantly affect viral replication. In contrast, treatment with these drugs inhibited TNF $\alpha$ secretion with or without infection, and budesonide or combination of budesonide and formoterol inhibited CXCL8 secretion after infection. When considered together, these findings suggest that budesonide and formoterol hinder $\mathrm{BE}$ cell secretion of specific proinflammatory cytokines without affecting epithelial antiviral responses.

Another goal of these studies was to test for allergic asthma effects on epithelial cell immune responses to RV. In cells from normal individuals, RV infection induced secretion of CXCL10 and TNF $\alpha$; these responses were significantly blunted in the asthma group. Furthermore, although levels of interferon protein secretion were undetectable in most cultures, viral infection consistently upregulated IFNB1 and IL28 mRNA, and these responses were also lower in the asthma group. Some $[27,28]$, but not all $[17,18,29]$, previous studies have

Table 4 Effects of asthma status on baseline (Mock) and RV-induced cytokine secretion and interferon mRNA expression (geometric mean, $95 \% \mathrm{Cl}$ )

\begin{tabular}{|c|c|c|c|c|}
\hline \multicolumn{2}{|l|}{ Cytokine } & \multirow{2}{*}{$\begin{array}{c}\text { Normal } \\
3.4(2.2,5.1)\end{array}$} & \multirow{2}{*}{$\begin{array}{c}\text { Asthma } \\
5.3(3.5,8.2)\end{array}$} & \multirow{2}{*}{$\begin{array}{c}\begin{array}{c}\text { P value (asthma } \\
\text { vs. normal) }\end{array} \\
0.06\end{array}$} \\
\hline$\overline{C X C L 10}$ & Mock & & & \\
\hline & RV & $50.6(21.6,118.1)^{* *}$ & $10.1(4.2,24.4)$ & 0.003 \\
\hline \multirow{2}{*}{$\begin{array}{l}\text { TNFa } \\
(\mathrm{pg} / \mathrm{mL})\end{array}$} & Mock & $3.2(1.3,7.9)$ & $1.4(0.6,3.5)$ & 0.02 \\
\hline & RV & $4.7(1.9,11.3)^{*}$ & $1.4(0,6,3.5)$ & 0.0003 \\
\hline \multicolumn{2}{|c|}{$\begin{array}{l}\text { IFNB1 mRNA } \\
\text { (fold increase) }\end{array}$} & $3.4(2.2,5.3)$ & $1.5(1.0,2.5)$ & 0.01 \\
\hline \multicolumn{2}{|c|}{$\begin{array}{l}\text { IL28 mRNA } \\
\text { (fold increase) }\end{array}$} & $49(21,112)$ & $9.2(3.8,22)$ & 0.009 \\
\hline
\end{tabular}

*P $=0.006$, ** $P<0.0001$ for RV vs. mock-infected samples. suggested that epithelial cell interferon responses are lower in BE cells from subjects with asthma, and these low interferon responses were inversely related to viral replication. In contrast, interferon responses were positively related to viral replication in our study, and the lower interferon responses observed in the asthma group were associated with a trend for lower viral replication. Although the reason for lower replication in the asthma group is unclear, we speculate that use of inhaled or oral corticosteroids by the subjects with asthma could have suppressed ICAM-1 expression, and that this suppression may have persisted through several cell generations in tissue culture. Interestingly, post hoc analyses suggest that allergic asthma status also affected the relationship between viral replication and induction of CXCL10, a chemokine for Th1 cells and mononuclear cells that is strongly induced by RV infection both in vitro and in vivo $[10,17,30]$. In our study, the positive correlation between RV RNA and CXCL10 mRNA and protein was blunted in subjects with allergic asthma (Figure 4C and 4D). Additional studies are warranted to determine whether this effect is also present in vivo.

Budesonide and formoterol combination therapy has been used extensively in the treatment of asthma, and controls daily symptoms as well as reducing the risk for asthma exacerbations [4]. The fact that most asthma exacerbations in children and about half of those in adults have viral infection as a contributing factor [31] suggests that combination therapy may specifically inhibit virusinduced exacerbations. Our findings as well as some previously published in vitro results $[24,25]$ suggest that budesonide and formoterol-mediated reduction of $\mathrm{BE}$ cell inflammatory responses may contribute to this effect. Skevaki et al. [25] have shown that the combination of budesonide and formoterol administered post infection suppressed RV-induced pro-inflammatory cytokines 

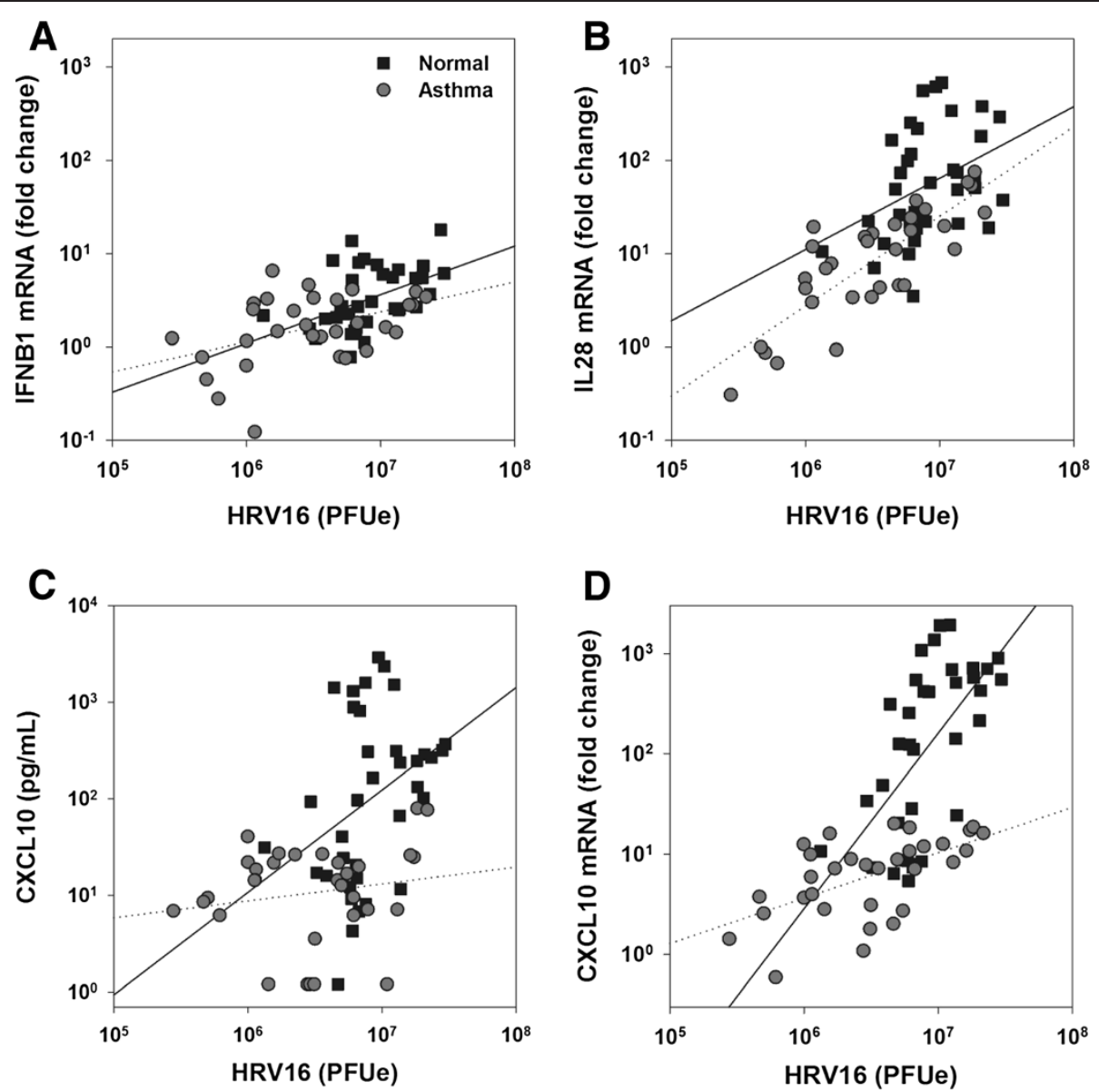

Figure 4 Correlations between RV RNA levels and cytokine responses in BE cells. RV RNA $24 \mathrm{~h}$ after inoculation was positively associated with IFNB1 mRNA ( $\boldsymbol{A})$, IL28 mRNA (B), and CXCL10 cytokine secretion (C) and mRNA upregulation (D). Samples include untreated samples and also those treated with budesonide, formoterol, and the combination. Results from samples in the normal and asthma groups are indicated by squares and circles, respectively, and separate regression lines (solid line, normal; dotted line, asthma) are plotted for each group.

(CCL5, CXCL8 and CXCL10) and the remodelingassociated growth factor (VEGF) in BE cells in a synergistic or additive manner. In our experimental model, pre-treatment with budesonide alone or in combination with formoterol also inhibited pro-inflammatory cytokines (CXCL10, TNF $\alpha$ and CXCL8) at baseline and/or after RV infection. Synergistic or additive suppression of RV-induced chemokines was also observed after pre-treatment of cultured BE cells with fluticasone propionate and salmeterol [14]. In RV-stimulated peripheral blood mononuclear cells, the combination of budesonide and formoterol inhibited CXCL10 and also antiviral responses (IFN- $\alpha$ secretion and expression of the type I interferon inducible genes) [15]. In contrast, we did not observe significant inhibitory effects of the drugs on RV-induced upregulation of CXCL10 secretion or type I and III interferon genes (e.g. IFNB1 and IL28) in primary BE cells. Interestingly, RV-16 infection has been shown to reduce glucocorticoid sensitivity of airway epithelial cells in vitro through activation of
c-Jun N-terminal kinase (JNK) and nuclear factor $\mathrm{\kappa B}$ (NF-kB) signaling pathways; however, potential effects of combined treatment with beta agonists have not been studied [32].

This study has several strengths, and some limitations, that should be considered in interpreting these results. Strengths of the study include the use of primary cultures of BE cells, as well as including cells from donors who were characterized for allergy and asthma. The donors had moderate or severe allergic asthma with well-characterized abnormalities in lung function. Furthermore, we used highly purified preparations of RV16 , as well as sensitive and specific viral diagnostics (real-time RT-PCR) for these studies. One limitation of the study is that the asthma and no asthma groups also differed in allergic status, and so some of the differences attributed to asthma could be mediated by allergy. In addition, each of the subjects with asthma was treated with inhaled or oral corticosteroids, and these medications were continued up until the time of bronchoscopy 
for reasons of safety. Although effects of the corticosteroid preparations may have been partially washed out under the conditions in tissue culture, pre-study treatment could have influenced findings in vitro. These in vitro studies enabled us to isolate responses of $\mathrm{BE}$ cells to virus and drugs, however, it is obvious that epithelial cell responses to viral infection as well as viral clearance are affected by other cells and cytokines in the airway milieu [33,34], and correlation with clinical findings is needed to establish relevance in vivo. It has been shown that the proportion of RV-16-infectible airway epithelial cells is relatively low (less 10\%) in both monolayer cultures and bronchial tissue samples infected ex vivo primarily due to a low basal expression of ICAM-1, the receptor for RV-16 and other major group viruses [35]. Therefore, the modest magnitude of virusspecific cytokine induction in these experiments was likely due to restriction of infection to the small subset of BE cells that express ICAM-1.

\section{Conclusions}

In summary, these findings indicate that budesonide and formoterol can inhibit inflammatory responses in vitro in primary BE cells without affecting viral replication or interfering with induction of the antiviral genes IFNB1 and IL28. These effects could potentially contribute to beneficial effects of budesonide and budesonide/formoterol combination therapy in preventing RV-induced asthma exacerbations in vivo. Furthermore, our results raise additional questions about the etiology and potential clinical significance of asthma-related differences in BE cell responses to RV infection.

\section{Competing interests}

This work was supported by investigator-initiated research grant from AstraZeneca. YAB, RAB and MDE declare that they have no competing interests. WWB provides advisory board services to Merck; consulting services to Amgen, Novartis, GlaxoSmithKline, Medlmmune, and Genentech; is a member of Data Monitoring Boards and Study Oversight Committees for Boston Scientific, Genentech, and ICON; receives royalties from Elsevier, and receives $\mathrm{NIH}$ grant support from $\mathrm{NIH}-\mathrm{NIAID}$ and $\mathrm{NIH}-\mathrm{NHLBI}$. CM and $\mathrm{AML}$ are employees of AstraZeneca. JEG has grant funding from GlaxoSmithKline and Merck and is a consultant to AstraZeneca, GlaxoSmithKline, Merck, Gilead, Johnson \& Johnson, and Boehringer Ingelheim.

\section{Authors' contributions \\ YAB participated in the study design, performed experiments, analyzed data and drafted the manuscript. WWB and NNJ participated in the study design and interpretation of data. RAB assisted with cell culture. MDE contributed to data analysis. CM and AML participated in data analysis and writing of the manuscript. JEG designed the project, analyzed data and was the senior author of the paper. All authors read and approved the final manuscript.}

\section{Acknowledgments}

The authors thank Ms Susan Costello for her technical assistance. This work was supported by investigator-initiated research grant from AstraZeneca.

\section{Author details}

'Department of Pediatrics, University of Wisconsin-Madison, 600 Highland Avenue, K4/945 CSC, Madison, WI 53792-9988, USA. ${ }^{2}$ Department of
Medicine, University of Wisconsin-Madison, Madison, WI, USA. ${ }^{3}$ Department of Bioinformatics, University of Wisconsin-Madison, Madison, WI, USA.

${ }^{4}$ AstraZeneca R\&D Mölndal, Mölndal, Sweden.

Received: 8 May 2013 Accepted: 28 September 2013

Published: 4 October 2013

\section{References}

1. Friedlander SL, Busse $W W$ : The role of rhinovirus in asthma exacerbations. J Allergy Clin Immunol 2005, 116:267-273.

2. Johnston SL, Pattemore PK, Sanderson G, Smith S, Lampe F, Josephs L, et al: Community study of role of viral infections in exacerbations of asthma in 9-11 year old children. BMJ 1995, 310:1225-1229.

3. Wells KE, Peterson EL, Ahmedani BK, Severson RK, Gleason-Comstock J, Williams LK: The relationship between combination inhaled corticosteroid and long-acting beta-agonist use and severe asthma exacerbations in a diverse population. J Allergy Clin Immunol 2012, 129:1274-1279.

4. Chung KF, Caramori G, Adcock IM: Inhaled corticosteroids as combination therapy with beta-adrenergic agonists in airways disease: present and future. Eur J Clin Pharmacol 2009, 65:853-871.

5. Bateman ED, Harrison TW, Quirce S, Reddel HK, Buhl R, Humbert M, et al: Overall asthma control achieved with budesonide/formoterol maintenance and reliever therapy for patients on different treatment steps. Respir Res 2011, 12:38.

6. Reddel HK, Jenkins C, Quirce S, Sears MR, Bateman ED, O'Byrne PM, et al: Effect of different asthma treatments on risk of cold-related exacerbations. Eur Respir J 2011, 38:584-593.

7. Silvestri M, Serpero L, Petecchia L, Sabatini F, Cerasoli F Jr, Rossi GA: Cytokine-activated bronchial epithelial cell pro-inflammatory functions are effectively downregulated in vitro by ciclesonide. Pulm Pharmacol Ther 2006, 19:210-217.

8. Sabatini F, Silvestri M, Sale R, Serpero L, Raynal ME, Di BP, et al: Modulation of the constitutive or cytokine-induced bronchial epithelial cell functions in vitro by fluticasone propionate. Immunol Lett 2003, 89:215-224.

9. Grunberg K, Sharon RF, Hiltermann TJ, Brahim JJ, Dick EC, Sterk PJ, et al: Experimental rhinovirus 16 infection increases intercellular adhesion molecule-1 expression in bronchial epithelium of asthmatics regardless of inhaled steroid treatment. Clin Exp Allergy 2000, 30:1015-1023.

10. Spurrell JC, Wiehler S, Zaheer RS, Sanders SP, Proud D: Human airway epithelial cells produce IP-10 (CXCL10) in vitro and in vivo upon rhinovirus infection. Am J Physiol Lung Cell Mol Physiol 2005, 289:L85-L95.

11. Schroth MK, Grimm E, Frindt P, Galagan DM, Konno SI, Love R, et al: Rhinovirus replication causes RANTES production in primary bronchial epithelial cells. Am J Respir Cell Mol Biol 1999, 20:1220-1228.

12. Kirchberger S, Majdic O, Stockl J: Modulation of the immune system by human rhinoviruses. Int Arch Allergy Immunol 2007, 142:1-10.

13. Kallal $L E$, Lukacs NW: The role of chemokines in virus-associated asthma exacerbations. Curr Allergy Asthma Rep 2008, 8:443-450.

14. Edwards MR, Johnson MW, Johnston SL: Combination therapy: synergistic suppression of virus-induced chemokines in airway epithelial cells. Am J Respir Cell Mol Biol 2006, 34:616-624.

15. Davies JM, Carroll ML, Li H, Poh AM, Kirkegard D, Towers M, et al: Budesonide and formoterol reduce early innate anti-viral immune responses in vitro. PLoS One 2011, 6:e27898.

16. Gustafson LM, Proud D, Hendley JO, Hayden FG, Gwaltney JM Jr: Oral prednisone therapy in experimental rhinovirus infections. J Allergy Clin Immunol 1996, 97:1009-1014.

17. DeMore JP, Weisshaar EH, Vrtis RF, Swenson CA, Evans MD, Morin A, et al: Similar colds in subjects with allergic asthma and nonatopic subjects after inoculation with rhinovirus-16. J Allergy Clin Immunol 2009, 124:245-52. 252

18. Bochkov YA, Hanson KM, Keles S, Brockman-Schneider RA, Jarjour NN, Gern JE: Rhinovirus-induced modulation of gene expression in bronchial epithelial cells from subjects with asthma. Mucosal Immunol 2010, 3:69-80.

19. Lee WM, Wang WS, Rueckert RR: Complete sequence of the RNA genome of human rhinovirus 16 , a clinically useful common cold virus belonging to the ICAM-1 receptor group. Virus Genes 1995, 9:177-181.

20. Mosser AG, Vrtis R, Burchell L, Lee WM, Dick CR, Weisshaar E, et al: Quantitative and qualitative analysis of rhinovirus infection in bronchial tissues. Am J Respir Crit Care Med 2005, 171:645-651. 
21. Sherry B, Rueckert R: Evidence for at least two dominant neutralization antigens on human rhinovirus 14. J Virol 1985, 53:137-143.

22. He JQ, Sandford AJ, Wang IM, Stepaniants S, Knight DA, Kicic A, et al: Selection of housekeeping genes for real-time PCR in atopic human bronchial epithelial cells. Eur Respir J 2008, 32:755-762.

23. Holgate ST, Roberts G, Arshad HS, Howarth PH, Davies DE: The role of the airway epithelium and its interaction with environmental factors in asthma pathogenesis. Proc Am Thorac Soc 2009, 6:655-659.

24. Korn SH, Jerre A, Brattsand R: Effects of formoterol and budesonide on GM-CSF and IL-8 secretion by triggered human bronchial epithelial cells. Eur Respir J 2001, 17:1070-1077.

25. Skevaki CL, Christodoulou I, Spyridaki IS, Tiniakou I, Georgiou V, Xepapadaki $P$, et al: Budesonide and formoterol inhibit inflammatory mediator production by bronchial epithelial cells infected with rhinovirus. Clin Exp Allergy 2009, 39:1700-1710

26. Strandberg K, Palmberg L, Larsson K: Effect of budesonide and formoterol on IL- 6 and IL-8 release from primary bronchial epithelial cells. J Asthma 2008, 45:201-203.

27. Wark PA, Johnston SL, Bucchieri F, Powell R, Puddicombe S, Laza-Stanca V, et al: Asthmatic bronchial epithelial cells have a deficient innate immune response to infection with rhinovirus. J Exp Med 2005, 201:937-947.

28. Contoli M, Message SD, Laza-Stanca V, Edwards MR, Wark PA, Bartlett NW, et al: Role of deficient type III interferon-lambda production in asthma exacerbations. Nat Med 2006, 12:1023-1026.

29. Lopez-Souza N, Favoreto S, Wong H, Ward T, Yagi S, Schnurr D, et al: In vitro susceptibility to rhinovirus infection is greater for bronchial than for nasal airway epithelial cells in human subjects. J Allergy Clin Immunol 2009, 123:1384-1390.

30. Wark PA, Bucchieri F, Johnston SL, Gibson PG, Hamilton L, Mimica J, et al: IFN-gamma-induced protein 10 is a novel biomarker of rhinovirusinduced asthma exacerbations. J Allergy Clin Immunol 2007, 120:586-593.

31. Gern JE: The ABCs of rhinoviruses, wheezing, and asthma. J Virol 2010, 84:7418-7426.

32. Papi A, Contoli M, Adcock IM, Bellettato C, Padovani A, Casolari P, et a: Rhinovirus infection causes steroid resistance in airway epithelium through nuclear factor kappaB and c-Jun N-terminal kinase activation. J Allergy Clin Immunol 2013. (in press) http://dx.doi.org/10.1016/j. jaci.2013.05.028

33. Korpi-Steiner NL, Valkenaar SM, Bates ME, Evans MD, Gern JE, Bertics PJ: Human monocytic cells direct the robust release of CXCL10 by bronchial epithelial cells during rhinovirus infection. Clin Exp Allergy 2010, 40:1203-1213.

34. Kato A, Favoreto S Jr, Avila PC, Schleimer RP: TLR3- and Th2 cytokinedependent production of thymic stromal lymphopoietin in human airway epithelial cells. J Immunol 2007, 179:1080-1087.

35. Mosser AG, Brockman-Schneider RA, Amineva SP, Burchell L, Sedgwick JB, Busse WW, et al: Similar frequency of rhinovirus-infectable cells in upper and lower airway epithelium. J Infect Dis 2002, 185:734-743.

doi:10.1186/1465-9921-14-98

Cite this article as: Bochkov et al:: Budesonide and formoterol effects on rhinovirus replication and epithelial cell cytokine responses. Respiratory Research 2013 14:98.

\section{Submit your next manuscript to BioMed Central and take full advantage of:}

- Convenient online submission

- Thorough peer review

- No space constraints or color figure charges

- Immediate publication on acceptance

- Inclusion in PubMed, CAS, Scopus and Google Scholar

- Research which is freely available for redistribution

Submit your manuscript at www.biomedcentral.com/submit
Biomed Central 